Northwestern University School of Law

Northwestern University School of Law Scholarly Commons

Faculty Working Papers

2008

\title{
Contested Morality: Judge Posner on Infanticide, Slavery, Suttee, Female Genital Mutilation, and the Holocaust
}

Anthony D'Amato

Northwestern University School of Law, a-damato@law.northwestern.edu

\section{Repository Citation}

D'Amato, Anthony, "Contested Morality: Judge Posner on Infanticide, Slavery, Suttee, Female Genital Mutilation, and the Holocaust" (2008). Faculty Working Papers. Paper 162.

http://scholarlycommons.law.northwestern.edu/facultyworkingpapers/162

This Working Paper is brought to you for free and open access by Northwestern University School of Law Scholarly Commons. It has been accepted for inclusion in Faculty Working Papers by an authorized administrator of Northwestern University School of Law Scholarly Commons. 


\title{
CONTESTED MORALITY: JUDGE POSNER
}

\section{ON INFANTICIDE, SLAVERY, SUTTEE, FEMALE \\ GENITAL MUTILATION, AND THE HOLOCAUST}

\author{
by Anthony D’Amato*
}

Judges are notoriously reluctant to reveal their out-of-court positions on contested issues of morality. Judge Patrick Devlin is one exception; his work has been the subject of considerable academic commentary. ${ }^{1}$ The other notable exception is Judge Richard Posner of the Seventh Circuit Court of Appeals in Chicago. But unlike Judge Devlin’s, Judge Posner's writings on morality have largely been bypassed. Yet he is one of America's most influential jurists. The present Article examines the meaning that Judge Posner ascribes to morality and analyzes the way he applies his concept of morality to five controversial topics of his choice: infanticide, slavery, suttee, female genital mutilation, and the Holocaust. ${ }^{2}$

In 1997 Judge Posner was invited to give the prestigious Holmes Lectures at Harvard Law School. He revised and expanded the lectures in his book The Problematics of Moral and Legal Theory ${ }^{3}$ The primary target of his lectures and book is academic moralists - those who argue that morality should play a role in the law, a role that runs

\footnotetext{
${ }^{*}$ Leighton Professor of Law, Northwestern University

${ }^{1}$ Patrick Devlin, The Enforcement of Morals (1965). See Ronald Dworkin, Taking Rights Seriously (1977); H.L.A.. Hart, Law, Liberty, and Morality (1963).

${ }^{2}$ The present Article appears to be the only commentary on Judge Posner's analysis of those five topics. Two additional topics that he has taken up are abortion and physician-assisted suicide. His position on these topics has been examined critically in John Mikhail, Law, Science, and Morality: A Review of Richard Posner's The Problematics of Moral and Legal Theory (1999), 54 Stanford L.R. 1057 (2002).

${ }^{3}$ Richard A. Posner, The Problematics of Moral and Legal Theory (1999).
} 
the spectrum from suggestive to important to influential to decisive. More to the point, moralists such as Ronald Dworkin, John Finnis, Alan Gewirth, Thomas Nagel, Charles Fried, Martha Nussbaum, John Rawls, Joseph Raz, Thomas Scanlon, and Judith Jarvis Thomson, have directly criticized Judge Posner for allowing the dismal science of economics to trump moral sensibility. In his lectures and book he counterattacks on the broad ground that the academic moralists have not shown that morality has any useful content. In a more recent writing, he adds that his disbelief in universal moral law cannot be proved to be incorrect by anyone who reasons about moral questions from a perspective other than his own. ${ }^{4}$ Perhaps his signal claim is that "there are no convincing answers to contested moral questions unless the questions are reducible to ones of fact." ${ }^{5}$

Judge Posner begins his Problematics by disavowing moral relativism. He says "I am not a moral relativist in the 'anything goes' sense more accurately described as moral subjectivism or moral skepticism." ${ }^{6}$ It is difficult to pin down what he means by this assertion. Consider his statement that "the criteria for pronouncing a moral claim valid are given by the culture in which the claim is advanced rather than by some transcultural ('universal') source of moral values." At a minimum he is saying that morality varies according to the culture in which it is expressed. This means that for Judge Posner an act that is moral in one locality can be immoral in another. Yet what is a morality whose content changes from place to place other than relative morality? Judge Posner is apparently aiming for cultural moral relativism as opposed to individual moral relativism,

\footnotetext{
${ }^{4}$ Richard A. Posner, Pragmatic Liberalism versus Classical Liberalism, 71 U. Chicago Law Rev. 659, 668 (2004).

${ }^{5}$ Id. at 10 .

${ }^{6}$ Problematics 8.

${ }^{7}$ Ibid. It is unclear whether Judge Posner's position is empirically dependent upon there being more than one culture in the world.
} 
in which individuals are morally constrained by the moral precepts of their culture. While the content of the moral precepts may vary from culture to culture, Judge Posner regards this as an extrinsic fact that does not bear upon an individual's morality. For every individual is bound by, and cannot justifiably deviate from, the morality of the culture in which he happens to be located.

If Judge Posner's view of morality is not totally relative, it has a strong jurisdictional flavor. By analogy, a German citizen in Germany is not subject to the laws of France, and a French citizen in France is not subject to German law. French law is certainly extrinsic to a non-traveling German citizen. Law may vary in content from a macro point of view, but the individual citizen is faced with a fixed set of rules in his or her home territory. Judge Posner’s views on morality are explicable if one substitutes "law" for "morality."

Is morality jurisdictional? Or is Judge Posner's position more nuanced than that? To Judge Posner's credit the five examples he has chosen to apply his views on morality are not at all easy to analyze. Their mutual differences give us distinct windows to view the particulars of his moral theory.

\section{Infanticide}

“Infanticide,” Judge Posner writes, "is abhorred in our society but routine in ones that cannot feed all the children that are born.” ${ }^{8}$ His empirical observation taken alone might be correct, but the clear implication of the "but" in the middle of his sentence is the

\footnotetext{
${ }^{8}$ Id. at 19.
} 
claim that infanticide is abhorred in our society but not abhorred in societies that are at the starvation level. Yet how would he know that those societies (in which infanticide is routine) do not abhor the practice? A mother in a starving society may be grief-stricken that her newborn child must be killed. Why would it be inconsistent for her to abhor both the fact that the rulers of her society are living in extravagant luxury and the fact that she must kill her own child because she has no access to food? She and her friends might conceivably use Judge Posner's word routine, if they use it at all, to assuage their feelings of guilt — to reassure themselves that everybody has to do it. Or maybe they call it routine ironically. There is no inherent contradiction between routine and abhorrent. Is Judge Posner perhaps intimating that when people are starving they become morally indifferent to infanticide? At bottom he wants to show that morality changes its content in starving versus non-starving societies, thus proving his main point that moral standards are factdependent. But since the ordinary use of the term 'moral' is the characterizaation of a set of facts, it is hardly persuasive to turn the sentence around and say that facts themselves show the vacuity of the concept of morality.

Judge Posner seeks morality in the normal or routine behavior of societies, but not all abnormal behavior is immoral:

A person who murders an infant is acting immorally in our society; a person who sincerely claimed, with or without supporting evidence, that it is right to kill infants would be asserting a private moral position. But I would hesitate to call him immoral, just as I would hesitate to call Jesus Christ immoral for having violated settled norms of Judaism and Roman law or Pontius Pilate immoral for enforcing that law. ${ }^{9}$

\footnotetext{
${ }^{9}$ Id. at 10 .
} 
What precise analogies is Judge Posner making in this passage? It would seem to follow from his first sentence that a serial killer like Jeffrey Dahmer, who ate the flesh of innocent people out of a sincere belief that killing them was the right thing to do, was asserting a private moral position. Or Hitler, who sincerely believed that he was dedicating himself to the best interests of the German people, was being morally correct according to his own lights. To be sure, it is doubtless true that on the bench Judge Posner would convict a person like Dahmer, though not because the defendant acted immorally but because the defendant violated the criminal law. A defense to a crime based on sincerity would get nowhere in Judge Posner's courtroom. But a defense based on morality might get Judge Posner's attention. It might give Judge Posner occasion to cite John Austin, a leading theorist of positivism, who wrote in 1832 that

The most pernicious laws, and therefore those which are most opposed to the will of God, have been and are continually enforced as laws by judicial tribunals. Suppose an act innocuous, or positively beneficial, be prohibited by the sovereign under the penalty of death; if I commit this act, I shall be tried and condemned, and if I object to the sentence, that it is contrary to the law of God, who has commanded that human lawgivers shall not prohibit acts which have no civil consequences, the Court of Justice will demonstrate the inconclusiveness of my reasoning by hanging me up, in pursuance of the law of which I have impugned the validity. ${ }^{10}$

Although Judge Posner only mentions Jesus Christ and Pontius Pilate fleetingly, it is important to take these references seriously, especially because Judge Posner seems to believe that the lessons to be derived therefrom are obvious. Thus he says that he would "hesitate to call Jesus Christ immoral for having violated settled norms of Judaism.” What norms of Judaism does Judge Posner have in mind? Are they norms that are comparable

\footnotetext{
${ }^{10}$ John Austin, The Province of Jurisprudence Determined 158 (1995 ed.)
} 
to infanticide? Did Jesus Christ kill people or order them killed? Did he condone the killing of children? Or was he a thief? An arsonist? A terrorist? A traitor? He once angrily overturned a table belonging to money-changers in the Temple, but that act caused no lasting harm even if an economist might think it disgusting. There is no doubt that Jesus violated some of the stringent Jewish dietary laws and encouraged others to violate them, and furthermore he did not observe the Sabbath. But would these minor transgressions justify Judge Posner to hesitate before reaching the conclusion that Jesus was not immoral? What's the point of comparing infanticide with failure to observe the Sabbath?

The other Biblical personage whom Judge Posner hesitates to call immoral is Pontius Pilate. In Judge Posner's view, Pilate only enforced Roman law. In the case of Jesus Christ, the Roman law that Pilate was enforcing was the law against sedition. Let us consider what Pilate actually did.

Most obviously, nothing that Jesus preached can remotely be called seditious. ${ }^{11}$ Jesus preached the virtues of poverty, forgiveness, and charity to one’s neighbors. He said that evil should be met with nonresistance, that persecutors should be blessed and vengeance eschewed, that all taxes should be paid, all legal authorities should be honored, and that the people should repent of their sins and reform. Jesus told his followers: "Render unto Caesar the things which are Caesar's, and unto God the things

\footnotetext{
${ }^{11}$ A religion per se was not regarded as seditious. Although the Romans believed their own religion to be the only true religion, their attitude was that if outsiders did not understand the Roman religion to be the true religion, so much the worse for them. They simply were depriving themselves of the benefits of believing in the true religion.
} 
that are God's." ${ }^{\prime 2}$ Although there were preachers in Jesus' day who exhorted their followers to throw off the Roman yoke, Jesus was not one of them.

On Jesus' last and fateful entry into Jerusalem, the crowds swelled. Newcomers on the fringes of the crowds started the false rumor that Jesus was the long-awaited Messiah. This rumor attracted even more people to see Jesus and hear what he was saying. Pilate's spies and informers reported that potential trouble was brewing because of the ever-growing crowds that were listening to Jesus. Although Jesus' message was peaceful, the spies reported, the crowds might cajole him into leading a popular insurrection against Roman rule. Paula Fredriksen in her recent book concludes that Jesus "had in essence lost control of his audience." ${ }^{13}$ In modern terminology it would appear that Jesus’ preaching was inadvertently turning into a personality cult.

Pilate's advisers strategized that instead of attacking and killing the followers, just removing Jesus himself would probably break the back of his mission. Accordingly, Pilate commanded that Jesus be crucified with the mocking titulus on the cross: "Jesus of Nazareth, King of the Jews.” The plan worked perfectly. Jesus' demoralized followers drifted away, some went into hiding, and his closest acolyte, Peter, three times denied that he even knew Jesus.

When Judge Posner refrains from calling Pontius Pilate immoral for “enforcing” Roman law, he is impliedly justifying Pilate's decision to sacrifice a completely innocent person for the sake of heading off a possible insurrection. Undoubtedly there are people who would agree with Judge Posner's robust utilitarianism. They may feel that the price of law and order is the occasional sacrifice of an innocent person. They may think that

\footnotetext{
${ }^{12}$ Matt. 22:21.

${ }^{13}$ Paula Fredriksen, Jesus of Nazareth, King of the Jews 247 (1999).
} 
what Pilate did was praiseworthy because of its cost-effectiveness. They may believe that

Pilate’s act was moral. But this does not resolve the question of whether the meaning they attribute to the word "moral" is the same as that of the general linguistic community. ${ }^{14}$ Many people would say that killing an innocent person is per se immoral. Kant said that a person's life has infinite value and therefore no other goals can add up high enough in value to overcome infinity.

\section{Slavery}

Judge Posner argues that if there is at least one justification for slavery, then we cannot say that it is always wrong. He asserts:

Slavery was routine when the victors in war could not afford to feed or free their captives, so that the alternative to enslaving them was killing them. ${ }^{15}$

This argument, which originated in Aristotle and was championed by John Locke, needs to be trimmed down by moral considerations to make it a more debatable case for either its apologists or its opponents. Surely the argument cannot apply to victors in any war but only to victors in certain kinds of war. A victor on the side of the aggressor is morally bankrupt to begin with, and thus there is no morality in reserve, so to speak, to cover his enslavement of his captives. This is not true of course of the the opposing side which, fighting in self-defense, is morally situated to enslave its captives when there their

\footnotetext{
${ }^{14}$ Utilitarianism can reduce to “what people want.” Since people can want immoral things, utilitarianism itself does not necessarily set forth a moral position.

${ }^{15}$ Problematics 19.
} 
alternative is death or starvation. But even then it is only permissible to enslave the captives; their children, if any, should be born free. ${ }^{16}$

Although the foregoing are perhaps the two leading qualifications to Judge Posner's example, there are additional moral considerations. Why is "slavery” the only reasonable alternative to death or starvation in Judge Posner's example? Is it necessary to legislate that the vanquished soldiers have legally become chattels in order to ensure that they will not someday rise to fight again? ${ }^{17}$ Is it not possible to salvage their humanity by deeming them zero-class citizens_-persons with no political rights? They could still retain basic human rights such as the right to food, clothing, and shelter. Indeed, to take away those basic rights would contradict the original reason to spare them.

Judge Posner’s argument may reduce to the generalization that in some circumstances slavery can be the lesser of two evils. Most people including the captives would probably agree that when the alternative is death, a life of enslavement is preferable. Yet is calling slavery “the lesser of two evils” fair to Judge Posner's argument? Isn't Judge Posner saying that, in the case he invokes, enslavement is not an evil but rather is a good? Can something evil become good because of special circumstances? Or is an evil always an evil, even when it is a necessary evil?

This leads to the critical question whether the general meaning we apply to the term "enslavement” applies here. To avoid death must the captive become a slave in the general sense of that term as understood today by the relevant linguistic community? Or would Judge Posner's example be more morally compelling if the captive became a zeroclass citizen in the sense suggested above? The more we encounter definitional and

\footnotetext{
${ }^{16}$ Locke recognized both of these qualifications. He considered slavery justified only if it is restricted to first-generation captives of a just war.

${ }^{17}$ Spartacus and his followers were slaves when they revolted.
} 
linguistic problems, the less compelling seems Judge Posner's example. The slavery issue may be more definitional than factual. In any event it is not easily dismissed. Let us proceed.

\section{Suttee}

Judge Posner writes:

Had I been a British colonial official (but with my present values) in nineteenth-century India, I would have outlawed suttee (the immolation—nominally, at least, voluntary—of the widow on her husband's bier). I would have suppressed the practice because I found it disgusting, not because I found it immoral. Our reactions prove nothing about the wrongness of the "disgusting" morality. No doubt Hindu men thought widows who resisted their fate disgusting. ${ }^{18}$

This excerpt brings us closer to figuring out what Judge Posner means by 'morality. But let us first deal with the idea of 'disgust.' Steven Pinker, in How the Mind Works, writes that "disgust is a universal human emotion, signaled with its own facial expression and codified everywhere in food taboos."19 ${ }^{19}$ The word does not seem appropriate for one's reaction to a woman burning herself to death. Judge Posner appears to have some trouble finding synonyms for 'immoral,' but nevertheless he is determined to transvalue that word.

Verbal transvaluation is a practice that unfortunately has plagued the dialectics of much political and social theory since the Renaissance. A transvaluist uses a word to evoke the meaning that his reader associates with that word while at the same time

${ }^{18}$ Id. at $10-11$.

${ }^{19}$ Steven Pinker, How the Mind Works 378 (1997). 
shifting its meaning to advance his own special argument. Lenin’s term 'dictatorship of the proletariat' is an example of transvaluation, as are Proudhon's 'property is theft' and Mandeville’s 'greed is a public virtue.' Aristotle reserved the term 'sophistry' to designate those who engage in verbal transvaluation. We found in the previous section that Judge Posner may have transvalued the concept of slavery.

Perhaps one reason Judge Posner finds it easy to say that if he were a British colonial official in nineteenth century India he would have outlawed suttee, is that he is also quite ready to outlaw any practice in the United States today that he finds disgusting. For example, he strongly opposed making the Virginia Military Institute co-educational. He says in his heated criticism of the Supreme Court's decision in that case, "I happen to belong to the school of outrage., 20

If we turn from transvaluation to territorial morality, we find that the suttee example raises a harder problem for Judge Posner. Why would he, as a hypothetical British colonial officer in nineteenth-century India, have interfered with the cultural morality of the people by outlawing suttee? He appears to be arguing in a circle when he says that he retains his present values. For the application of his present values (which include opposition to suttee) forces his conclusion that he would outlaw suttee if he were anytime or anywhere else—such as a British official in nineteenth-century India.

Otherwise he would have to say that he has values but in this case has decided to ignore them.

To test Judge Posner's position for possible circularity, let us suppose that he does not retain his present values when he time-travels to nineteenth-century India. In that case he would simply be like any other colonial officer serving in India. He would probably be

\footnotetext{
${ }^{20}$ Problematics 171.
} 
tolerant of the practice of suttee if not in favor of it. We know this because historically the great majority of British colonial officers in nineteenth-century India did not interfere with suttee- they respected non-political native customs. But now we have reached a critical question, namely: Who exactly is the time traveler? It looks and acts like Judge Posner, but its mind is different. For in removing his present values that include an abhorrence of suttee, and replacing them with other values that include tolerance for suttee, many related and neighboring thoughts also must be modified or deleted. A mind that is intolerant of suttee has a vast set of interconnected beliefs relating to the equality of men and women, animal rights, and so on. These beliefs must be modified, changed, or deleted in order to make space for a tolerance of suttee. Otherwise the new tolerance would be hemmed in by contradictory thoughts relating to human rights and equality in general. It would leave the mind with massive cognitive dissonance. The mind itself would try to remove the dissonance by attacking and modifying the tolerance-for-suttee idea. In brief, it would be impossible or nearly impossible to change the time-traveler's attitude toward suttee and without disturbing or changing all the other thoughts and memories that constitute his mind. The only way to change the time-traveler's mind so as to accommodate the concept of suttee is to change it wholesale- - that is, to change it into a typical mind of a nineteenth-century British colonial officer. But if we do that, it would not be Judge Posner who is being sent back to the nineteenth century, but rather someone else whose mind is quite different. It would be a mind that is congruent with the mind of a nineteenth-century British colonial officer. Personal identity is, after all, determined by the mind and not by the body. ${ }^{21}$

\footnotetext{
${ }^{21}$ Although it is clearly preferable to be the donee and not the donor of an organ transplant, the situation is reversed if the brain is transplanted. One would clearly want to be the donor of the brain that is transplanted
} 
The foregoing argument proves:

(1) If Judge Posner travels back in time with his present values, he will simply apply those values to the target culture. This procedure will not yield any no new information (that is, nothing can be learned from it).

(2) If Judge Posner travels back in time with values that can be filled in by the target culture, it will not be Judge Posner that emerges from the time machine but rather a body that resembles Judge Posner's. This procedure cannot yield new information.

In conclusion, Judge Posner's suttee example does not help qualify his argument. ${ }^{22}$ We turn to the morality of female genital mutilation.

\section{Female Genital Mutilation}

The form of female circumcision that is called outside of Africa "female genital mutilation" consists of a removal by knife of the clitoris, the cutting of the labia majora and then the sewing together of the labia majora to cover the vagina, leaving a small opening to allow urine and menstrual blood to pass through. (On the night of her marriage, her husband cuts the threads open.) According to Amnesty International, over two million female circumcisions are performed each year, nearly all in a wide territorial

\footnotetext{
and not the donee.

${ }^{22}$ There is a way to support the practice of suttee on its merits although Judge Posner does not mention it. The practice of suttee must have strongly enhanced the bonds of husband and wife in nineteenth century India. If a man marries a woman knowing that she will throw herself on his funeral bier if his death precedes hers, perhaps he will respect and appreciate her more during his lifetime for giving him a future gift of such an immense sacrifice. Moreover, he may be less apprehensive about dying if he knows that his wife will make the journey to the afterlife next to him. This gives him another reason to be grateful to his wife. Of course, this argument is not convincing. But it serves a function similar to Locke's argument about slavery, supra.
} 
band that stretches from Senegal in West Africa to Somalia on the east coast, primarily in Muslim ar

eas. The term given to them is infibulation. Judge Posner explains the purpose of the procedure in his book Sex and Reason (1992):

By reducing the woman's capacity to experience sexual pleasure, the removal of the clitoris reduces the risk of a wife's committing adultery. ${ }^{23}$

Judge Posner goes on to justify the practice in economic terms: it is cheaper for the husband to marry a woman who has been the victim of genital mutilation than to hire detectives to watch over her during the day, when the husband is at work, to make sure that she does not commit adultery. Thus the practice of female circumcision is based on cost-effectiveness.

Where is Judge Posner's 'disgust' now that he seems to need it? It has apparently been trumped by family values:

[Defenders of female genital mutilation] claim that it is indispensable to maintaining the family in the circumstances in which the practice is followed. The claim is arguable. If it is correct, the moral critic is disarmed: for there is no lever for exalting individual choice or sexual pleasure over family values. ${ }^{24}$

Although we saw in the previous discussion of suttee that Judge Posner was willing to ignore family values, here they loom large. The high economic cost of surveillance of the wife during the day seems to tip the scale in favor of infibulation.. In contrast with the suttee case, where the cost of adding the widow to the top of the burning bier is trivial,

\footnotetext{
${ }^{23}$ Richard A. Judge Posner, Sex and Reason 257 (1992).
}

${ }^{24}$ Problematics 22. 
here the significant cost of surveillance must weigh heavily in Judge Posner's moral reasoning..

Judge Posner is always keen to find an economic rationale for a social practice that otherwise seems inexplicable. However, there is a downside associated with looking for economic explanations - the temptation to abandon the analysis as soon as the economic rationale is reached. Suppose we pursue the question of female genital mutilation beyond the limits that satisfy Judge Posner. We might ask why it is that many countries along the previously described wide territorial band in Africa have made female infibulation illegal. The legislators in these countries are almost exclusively male. If female infibulation benefits men as Judge Posner suggests it does (by reducing their surveillance costs), then why do these male legislative bodies enact laws, and retain them on the books, that criminalize the practice? Perhaps the men in those societies believe that a nonmonetary cost exceeds the economic benefit.

Let us accordingly consider the women who forcibly tie young girls to a tree and cut their labia. All those women were themselves infibulated when they were young. Perhaps they are now acting out of jealousy. They may not want sexual competition from the girls. Or they might not want to be confronted with the idea that a girl might derive pleasure from the act of sexual intercourse. Additionally there is the elemental motivation: "If it was good enough for me when I was your age, then it is good enough for you.” (With appropriate modifications, these arguments may explain the duration of other traditions in our society.)

There is another difference between infibulation and Judge Posner's previous example of suttee. The bereaved widow voluntarily threw herself upon the funeral bier, 
but young girls dread infibulation and resist it with all their might. The young girl is a dissident within the culture. The older women will pounce on her at night when she is asleep, take her to a tree and spread-eagle her body against it, and then without giving her any anesthetic proceed to cut her clitoris. They stuff a rag in her mouth to prevent screaming. Do these women and their beliefs constitute the 'locality' that is the source, for Judge Posner, of moral norms? Why isn't the victim of the genital mutilation also a locality—a locality of one? Why shouldn't her own moral norms block the moral norms of the women around her? Judge Posner earlier anticipated such an argument:

There is no inconsistency in saying that all moral truths are local but adding that one's own morality is hyperlocal, being limited to oneself. ${ }^{25}$

When we come to the topic of genital mutilation, should the principle of hyperlocality operate to protect the twelve-year-old girl facing infibulation? Judge Posner responds:

It is vacuous to complain that the mutilated girls are often too young to be able to make a responsible choice (assuming that they are even given a choice) of whether to undergo the procedure. The moral code of these societies is not founded on principles of freedom, autonomy, or equality, and there is no privileged standpoint from which to argue that it should be. $^{26}$

If there is no 'privileged standpoint,' then by what mechanism does Judge Posner privilege the moral code of the culture over the moral code of the twelve-year-old girl? It is not because the mutilators are older because Judge Posner's first sentence rules out the age factor.

\footnotetext{
${ }^{25} \mathrm{Id}$. at 9 .

${ }^{26} I d$. at 22.
} 
Let us compare and contrast the earlier example of slavery. Would Judge Posner say that it is arbitrary to listen to a slave's claim that slavery is immoral because the slave has neither freedom nor autonomy to make such a claim? Is Judge Posner assigning more power to dictatorial societies if they want to override individual moralities? Is he saying that hyperlocality depends on a moral code that includes freedom and equality? Is he saying that freedom and equality vary from culture to culture so that it is possible for one culture—call it the Orwellian culture—-to say that slavery is freedom? Perhaps Judge Posner is just asserting a point of personal privilege: that hyperlocality applies only to himself. It is hard to see how Judge Posner's inquiry into the morality of female genital mutilation has advanced his attempt to work out a space for himself between absolute and relative morality.

\section{The Holocaust}

Judge Posner has demonstrated through his writings a remarkable willingness to address any issue of public concern and importance no matter how politically sensitive that issue might be. Of the Holocaust he writes:

That the Nazis killed millions of defenseless civilians is a fact; its truth is independent of what anyone believes. That the Nazis' actions were morally wrong is a value judgment: it depends on beliefs that cannot be proved true or false. ${ }^{27}$

\footnotetext{
${ }^{27}$ Problematics at ix.
} 
Judge Posner is building upon Hume's famous argument that authors on morality often move imperceptibly from is-statements to ought-statements. ${ }^{28}$ If writers wish to derive an ought from an is, Hume added, they should give an explanation of how this is done.

The first of at least two conceptually different ways of responding to Judge Posner and to David Hume would be to argue that although most things in the world are exclusively factual, things that humans do are automatically invested with values. These values are connected to the survival of the human species. Evolution has hard-wired into our brains an instinct for placing a value on every choice we make. Each value can be positive or negative, but it is always a value. If the value is positive, it points in the direction of human survival. If we purchase a gun, our choice has a positive value if we intend it for self-defense and a negative value if we want to use it to commit suicide. Ayn Rand in her discussion of the virtues of selfishness regards as good the things that further our lives and as evil the things that threaten our lives. ${ }^{29}$ However she omits mention of one's progeny and one's neighbors. Darwin was interested in the survival of a species and not of an individual. By inference, every organism has species-survival genes that hard-wire the organism to regard as its own survival the survival of its progeny. Thus the mother who in dire circumstances lays down her life for her children is doing something that has a positive value. In addition, positive values spill over to our neighbors. There is a positive value in helping other people because species survival depends upon mutual help and nurturance. Society has motivated many persons to act as specialists in the survival of the general population, such as doctors, police officers, fire fighters, farmers, construction workers, and even entertainers (who may introduce enough fun and pleasure

\footnotetext{
${ }^{28}$ David Hume, A Treatise of Human Nature bk 3, pt. 1, sec. 1 (

${ }^{29}$ Ayn Rand, The Virtue of Selfishness 17 (1964).
} 
into living that people are less prone to despair and suicide.) People who create value for themselves or others are increasing the world's stock of positive values. The Nazi executioners, on the other hand, were adding negative value to the world. Thus, without invoking ought-statements, it is arguable as a factual matter that the Nazi executioners acted contrary to human values, that is, they acted immorally.

Secondly and apart from evolution, consider the psychological facts of the way the human mind is constructed. When we read or hear a word, we interpret it both logically and psychologically. Each word that we hear seems to enter our minds wrapped in the many layers of emotional associations that we have gathered over our lifetime. We interpret and understand words not just by their definitions (expressed as additional words) but by instantly recalling the emotions we attached to those words when we heard them in the past. The word we hear triggers other words, images, emotions, sensations, and memories. These multivariate factors add emotional dimensionality to the meanings of the words we hear. For example, suppose a person who knows nothing about Hitler is shown (a) a paragraph, and (b) a sentence. The paragraph contains items such as Hitler's birth date, the names of his parents, the number of rooms in the house in Bavaria in which he spent his childhood, his scores on kindergarten tests, the years he served in the German army, the years he was imprisoned and the name of the prison, the date on which he was elected Chancellor of Germany, and similar biographical facts. The sentence (b) says "Hitler was an evil man.” Which tells us more of what we are interested in knowing about Hitler—paragraph (a) or sentence (b)? Although “evil” expresses a value, it also conveys a great deal of factual information. ${ }^{30}$ Ruth Anna Putnam has argued that the

\footnotetext{
${ }^{30}$ Of course the fact that Hitler was evil tells us nothing about when he was born, when he served in the Army, and so forth. But the more basic question is: why would we want to know these biographical facts
} 
difficulty of distinguishing whether words like "evil,” "good,” "helpful,” “fair,” and

“just” are descriptive or normative is a good reason for abandoning the distinction. ${ }^{31}$

Advocacy in the courtroom usually demonstrates the persuasive superiority of a

recitation of facts over arguments explicitly couched in terms of fairness or morality. On

July 27, 1946, Sir Hartley Shawcross, Britain’s Chief Prosecutor at the Nuremberg

Tribunal, highlighted his summation against the German and Nazi leaders by reading a

description by a German eyewitness of a mass execution of Jews by one of Himmler’s

Action Groups in the Baltics:

Without screaming or weeping, these people undressed, stood around in family groups, kissed each other, said farewells, and waited for a sign from another SS man, who stood near the pit with a whip in his hand. During the fifteen minutes I stood nearby, I heard no plea for mercy. I watched a family of about eight people, a man and a woman of about fifty with two daughters of about twenty to twenty-four and boys of about one, eight, and ten. An old woman with snow-white hair was holding the one-year-old in her arms and singing to it and tickling it. The child was cooing with delight. The couple were looking on with tears in their eyes. The father was holding the hand of a boy about ten years old and speaking to him softly; the boy was fighting his tears. The father pointed to the sky, stroked his head and seemed to explain something to him. At that moment the SS man at the pit shouted something to his comrade who then counted off about twenty persons and instructed them to get down behind a mound of earth. Among them was the family I have mentioned.

An SS man sat on the edge of the narrow end of the pit, his feet dangling a Tommy gun on his knees. He was smoking a cigarette. The people, completely naked, went down some steps which were cut in the clay wall of the pit and clambered over the heads of the dead lying there, to the place to which the SS man directed them. They lay down in front of the dead or injured; some caressed those who were still alive and spoke to them

about Hitler? Except for special situations (conducting a census, for example), Hitler's biographical data are uninteresting per se. It is the moral fact about Hitler (that he is evil) that can make his biographical data interesting at least to those familiar with the context of that data.

31 See, e.g., Ruth Anna Putnam, Creating Facts and Values, 60 Philosophy 187 (1985); Ruth Anna Putnam, Perceiving Facts and Values, 73 Philosophy 5 (1998). 
in a low voice. Then I heard a series of shots. I looked into the pit and saw that the bodies were twitching or lying motionless on top of those before them. Blood was running from their necks. ${ }^{32}$

The German eyewitness was describing a value-laden activity. The word "immoral" would describe (with less specificity) the same event. We are hard-wired to view the killings as negatively valued-in other words, as immoral. If what the Nazi executioners did was not immoral (by anyone’s lights), what meaning could “immoral” possibly have? Perhaps Judge Posner’s long judicial experience has taught him how to short-circuit that hard wiring.

\section{Conclusion}

Judge Posner has tried to carve out a space for his own version of morality that lies somewhere in between universal and relative morality. He does not want to be a thoroughgoing relativist because that position reduces to a separate morality for every person. Hence he settles on culturally relativistic morality: each culture has a distinct morality that is binding only on the people living within it.

Although Judge Posner's position is forceful, intricate, and nuanced, this Article has attempted to show in detailed analysis that it is ultimately incoherent. If he had concluded simply that moral considerations have no place in his courtroom, then at least attorneys could know which kinds of arguments to avoid when appearing before him. Instead, it is ironic that for all he has disclosed about his approach to moral questions, the

\footnotetext{
${ }^{32}$ Quoted in Sereny, n. 22 supra, at 24-25.
} 
litigating attorney is left with no guidance. An attorney can read all his books and articles and still not have any idea of how to argue cases before him that involve questions of morality or fairness. (Perhaps this is what Judge Posner intends.) 